\title{
Assessment of Clinical Course, Prognostic Features, and Treatment Response of Patients with Chronic Lymphocytic Leukemia: A Single Center Experience
}

\section{Kronik Lenfositik Lösemi Tanılı Olguların Klinik Seyir, Prognostik Özellikler ve Tedavi Cevabı Yönünden Değerlendirilmesi: Tek Merkez Deneyimi}

\author{
Hacer Berna Afacan Öztürk, Murat Albayrak, Çiğdem Pala, Senem Maral, Abdulkerim Yıldız, Osman \\ Şahin, Pınar Cömert
}

University Of Health Sciences, Diskapi Yildirim Beyazit Training And Research Hospital, Department Of Hematology, Ankara, Turkey

Dergiye Ulaşma Tarihi: 17/09/2019 Dergiye Kabul Tarihi: 06/11/2019 Doi: 10.5505/aot.2019.41033

\section{ÖZET}

GÍRIŞ ve AMAÇ: Merkezimizde kronik lenfositik lösemi (KLL) tanısı ile takipte olan hastaların genel klinik özellikleri, ilk sıra tedavileri, olguların yaşam süreleri ve bu yanıtlara etkili olabilecek faktörleri değerlendirmeyi amaçladık.

YÖNTEM ve GEREÇLER: Çalışmada 2009-2018 yılları arasında Eğitim ve Araştırma Hastanesi Hematoloji Bölümünde KLL tanısı ile izlenen 188 hastanın dosyalarına ulaşılabilen 169'u retrospektif olarak değerlendirildi. BULGULAR: Çalışmaya alınan 169 hastadan 90’ı erkek, 79’u kadın, median yaş 65 (min37-max 89) idi. Tanı anında Rai evrelemesine göre değerlendirildiğinde evre 0 \%33,7 (n: 57), evre I \% 17,2 (n: 29), evre II \% 40,2 (n: 68), evre III \% 2,4 (n: 4), evre IV \% 6,5 (n: 11) olduğu tespit edildi. Takip süresi ortalama 42,57 aydı ve bu süreçte 134 hasta $(\% 79,2)$ hiç tedavi almazken, 35 hasta $(\% 20,7)$ tedavi aldı. İlk sıra tedaviler incelendiğinde tedavi alan 35 hastanın; 16'si (\%45,7) Rituksimab-Fludurabin ve Siklofosfamid (R-FC), 5'i (\%14,2) Fludarabin,Siklofosfamid (FC), 3'ü Klorambucil (\% 8,5), 5'i Rituksimab-Klorambucil (\% 14,2), 2'si Rituksimab, Siklofosfamid, Doksorubisin, Vinkristine, ve Prednisone kombinasyonu (R-CHOP) (\%5,7), 2'si RituksimabBendamustin (\%5,7), 1'i Siklofosfamid, Vinkristine, ve Prednisone kombinasyonu (CVP) ve 1'i CVP (\%2,8) aldığı görüldü. Tedavi almayan hastaların ortalama yaşam süresinin 99,4 ay, tedavi alan hastaların ortalama yaşam süresinin 89,7 ay olduğu tespit edilmiştir. Hastaların $38^{\prime}$ 'in de $(\% 22,5)$ mortalite izlendi. TARTIŞMA ve SONUÇ: Hastalarımızın demografik özelliklerinin diğer çalışmalarla benzer olduğu görülmüştür. Tedavi alma durumuna göre sağ kalım süresi incelendiğinde yaşam sürelerinin tedavi almayan grupta, tedavi alan gruba göre önemli düzeyde yüksek olduğu tespit edilmiştir.

Anahtar Kelimeler: Kronik Lenfositik Lösemi, Klinik Özellikler, Tek Merkez Deneyimi

\section{ABSTRACT}

INTRODUCTION: We aimed to assess patients with chronic lymphocytic leukemia (CLL) with respect to their general clinical features, first-line treatments, survival time, and factors affecting treatment response. METHODS: This study retrospectively enrolled 169 patients with available medical records of 188 patients who were under follow-up with CLL at Training and Research Hospital, Department of Hematology between 2009 and 2018.

RESULTS: Among 169 patients enrolled in the study, 90 were male and 79 were female; the study population had a median age of 65 ( $\min 37-\max 89)$ years. An analysis of Rai staging at the time of diagnosis revealed that fifty-seven (33.7\%) patients had stage 0 disease; twenty-nine (17.2\%) stage 1 disease; sixty-eight $(40.2 \%)$ stage 2 disease; four (2.4\%) patients stage 3 disease; and eleven $(6.5 \%)$ patients stage IV disease. The mean duration of follow-up was 42.57 months; during that period, 134 (79.2\%) patients received no therapy, and 35 (20.2\%) patients received therapy. The first-line therapy was administered to 35 patients, of whom $16(45.7 \%)$ received Rituximab-Fludarabin and Cyclophosphamide (R-FC); 5 (14.2\%) Fludarabin and Cyclophosphamide (FC); 3 $(8.5 \%)$ chlorambucil; $5(14.2 \%)$ Rituximab-Chlorambucil; $2(5.7 \%)$ the combination of Rituximab, 
Cyclophosphamide, Doxorubicin, Vincristine, and Prednisone (R-CHOP); 2 (5.7\%) Bendamustine; 1 (2.8\%) the combination of cyclophosphamide, vincristine, and prednisone (CVP) and 1 (2.8\%) Rituximab-CVP. The mean survival time of the untreated patients and treated patients were 99.4 months and 89.7 months, respectively. Thirty-eight $(22.5 \%)$ patients died.

DISCUSSION AND CONCLUSION: The demographic features of our patients were similar to those reported in previous studies. An analysis of treatment-based survival time revealed that it was significantly longer in the untreated patients than the treated ones.

Keywords: Chronic Lymphocytic Leukemia, Clinical Features, A Single Center Experience

\section{INTRODUCTION}

Chronic Lymphocytic Leukemia (CLL), the most common type of leukemia of adulthood in the Western countries, is characterized by the proliferation of mature-looking neoplastic B lymphocytes in lymphoid tissues such as peripheral blood, bone marrow, lymph nodes, spleen, and liver. Its diagnosis is made by a Blymphocyte count greater than $5000 / \mathrm{mm}^{3}$ in peripheral blood, and those lymphocytes having specific immunophenotypic features for CLL in flow cytometry. The characteristic phenotype contains CD5, CD19, and CD23 whereas they contain few or no CD20, surface immunoglobulin, CD79b, or FMC7 (1). CLL is diagnosed by flow cytometric examination from hemogram, peripheral blood, and peripheral smear. Unlike other leukemias, routine bone marrow examination is not recommended unless unexplained cytopenia exists.

The mean expected survival of patients with CLL is 10 years, although survival time ranges between months and years. Some patients have a long survival while others suffer an accelerated course and early death. Rai and Binet staging systems are simple but reliable prognostic systems that are based on physical examination and full blood count results. However, the fact that some low-stage patients have poor prognosis necessitates the use of other prognostic factors for staging $(2,3)$. Apart from staging systems, a variety of studies have been performed to determine the prognosis of the disease. Independent parameters other than stage have been shown to carry prognostic implications. Among poor prognostic markers are a bone marrow involvement of $>80 \%$; a peripheral blood prolymphocyte ratio of $>10 \%$; a leukocyte count of $>50 \times 10^{9} / \mathrm{L}$ at the time of diagnosis, elevated serum lactate dehydrogenase (LDH) level; elevated beta- 2 microglobulin level; and a short lymphocyte count doubling time
(LDT). Additionally, timidine kinase, sCD23, and sCD44, cytogenetic anomalies; IgVH mutation status; $\mathrm{CD} 38$ expression rate; and ZAP70 expression can be regarded as poor prognosticators $(4,5,6)$.

We aimed to contribute to the existing literature by retrospectively reviewing the demographic data, clinical features, prognostic markers, applied treatments, survival status of patients with chronic lymphocytic leukemia (CLL) who were under the follow-up at Training and Research Hospital, Department of Hematology.

\section{MATERIALS and METHOD}

Our study retrospectively assessed demographic and clinical features, prognostic markers, first-line therapies, and the effect of therapy on survival time among patients with chronic lymphocytic leukemia (CLL), who were diagnosed and followed at Training and Research Hospital, Department of Hematology. Information about patient demographics, full blood count parameters, flow cytometry features, splenomegaly status, deletion $17 \mathrm{p}$, bone marrow infiltration, applied treatments and treatment responses, and survival status were obtained from personal medical and hospital records. Statistical analysis was performed with SPSS 20.0 for windows software package. Kaplan-Meier test was used to calculate overall survival time.

\section{RESULTS}

Among 169 patients enrolled in the study,90 were male and 79 were female; the study population had a median age of $65(\min 37$ max 89) years. Laboratory tests at the time of diagnosis revealed a mean hemoglobin count of $12,86 \mathrm{gr} / \mathrm{dl} \pm 2,13$, a mean leukocyte count of $3,8 \times 10^{4} / \mu \mathrm{L}$, and a mean thrombocyte count of $1,99 \times 10^{5} / \mu \mathrm{L}$ (Table 1). All patients were diagnosed with flow cytometry. An analysis of 
Rai staging at the time of diagnosis revealed that fifty-seven $(33.7 \%)$ patients had stage 0 disease; twenty-nine (17.2\%) stage 1 disease; sixty-eight (40.2\%) stage 2 disease; four (2.4\%) patients stage 3 disease; and eleven $(6.5 \%)$ patients stage IV disease.

\begin{tabular}{|c|c|c|c|c|}
\hline Variables $(N=169)$ & $\mathrm{n}$ & $\%$ & Mean \pm S.D. & Median [Min-Max] \\
\hline $\begin{array}{l}\text { Sex } \\
\text { Female } \\
\text { Male }\end{array}$ & $\begin{array}{l}79 \\
90\end{array}$ & $\begin{array}{l}46,7 \\
53,3\end{array}$ & & \\
\hline Age (years) & & & $64,73 \pm 11,82$ & $65,0[37,0-89,0]$ \\
\hline $\begin{array}{l}\text { Splenomegaly } \\
\text { Yes } \\
\text { No }\end{array}$ & $\begin{array}{l}74 \\
95\end{array}$ & $\begin{array}{l}43,8 \\
56,2\end{array}$ & & \\
\hline $\begin{array}{l}\text { Treatment status } \\
\text { Untreated } \\
\text { Treated }\end{array}$ & $\begin{array}{l}127 \\
42\end{array}$ & $\begin{array}{l}75,1 \\
24,9\end{array}$ & & \\
\hline $\begin{array}{l}17 \mathrm{P} \\
\text { Negative } \\
\text { Positive }\end{array}$ & $\begin{array}{l}45 \\
7\end{array}$ & $\begin{array}{l}86,5 \\
13,5\end{array}$ & & \\
\hline $\begin{array}{l}\text { Autoimmune } \\
\text { Cytopenia } \\
\text { Yes } \\
\text { No }\end{array}$ & $\begin{array}{l}12 \\
157\end{array}$ & $\begin{array}{l}7,1 \\
92,9\end{array}$ & & \\
\hline $\begin{array}{l}\text { Secondary Tumor } \\
\text { Yes } \\
\text { No }\end{array}$ & $\begin{array}{l}15 \\
154\end{array}$ & $\begin{array}{l}8,9 \\
91,1\end{array}$ & & \\
\hline $\begin{array}{l}\text { Bone Marrow } \\
\text { infiltration } \\
\text { Present } \\
\text { Not performed }\end{array}$ & $\begin{array}{l}78 \\
91\end{array}$ & $\begin{array}{l}46,2 \\
53,8\end{array}$ & & \\
\hline LDH (U/L) & & & $238,39 \pm 108,81$ & $205,5[119,0-884,0]$ \\
\hline $\begin{array}{l}\text { Beta } 2 \text { Microglobulin } \\
\text { (mg/L) }\end{array}$ & & & $4,33 \pm 3,29$ & $3,4[0,1-20,4]$ \\
\hline Hemoglobin $(\mathrm{gr} / \mathrm{dl})$ & & & $12,86 \pm 2,13$ & $13,2[6,8-18,2]$ \\
\hline $\begin{array}{l}\text { Leukocyte (number } \\
/ \mu \mathrm{l} \text { ) }\end{array}$ & & & $38589,23 \pm 48777,11$ & $\begin{array}{l}23500,0 \\
{[3620,0-343200,0]}\end{array}$ \\
\hline $\begin{array}{l}\text { Thrombocyte } \\
\text { (number } / \mu \mathrm{l})\end{array}$ & & & $199402,37 \pm 83946,64$ & $\begin{array}{l}193000,0 \\
{[13000,0-524000,0]}\end{array}$ \\
\hline 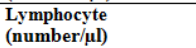 & & & $29415,33 \pm 40336,71$ & $\begin{array}{l}16600,0 \\
{[5000-277720,0]}\end{array}$ \\
\hline $\begin{array}{l}\text { RAI Stage } \\
0 \\
1 \\
2 \\
3 \\
4\end{array}$ & $\begin{array}{l}57 \\
29 \\
68 \\
4 \\
11\end{array}$ & $\begin{array}{l}33,7 \\
17,2 \\
40,2 \\
2,4 \\
6,5\end{array}$ & & \\
\hline $\begin{array}{l}\text { Survival status } \\
\text { Deceased } \\
\text { Surviving }\end{array}$ & $\begin{array}{l}38 \\
131\end{array}$ & $\begin{array}{l}22,5 \\
77,5\end{array}$ & & \\
\hline $\begin{array}{l}\begin{array}{l}\text { Follow-up } \\
\text { (months) }\end{array} \\
\text { duration }\end{array}$ & & & $42,57 \pm 28,13$ & $37,0[0,5-109,3]$ \\
\hline
\end{tabular}

At the time of diagnosis $83(49.1 \%)$ patients had splenomegaly but $86(50.9 \%)$ did not. During their follow-up, $12(7.1 \%)$ patients developed immunocytopenia; of these, 8 developed autoimmune hemolytic anemia, 3 immune thrombocytopenia, 1 both autoimmune hemolytic anemia and immune thrombocytopenia. Fifteen $(8.9 \%)$ patients developed a secondary malignancy anytime during follow-up. Of 52 patients having undergone deletion $17 \mathrm{p}$ analysis, $45(86.5 \%)$ were negative and $7(13.5 \%)$ were positive. The mean duration of follow-up was $42,57 \pm 28,13$ months; during that period, 134 (79.2\%) patients received no therapy but 35 (20.2\%) patients received therapy. The first-line therapy was administered to 35 patients, of whom 16 (45.7\%) received Rituximab-Fludurabin ve Cyclophosphamide (R-FC); 5 (14.2\%) Fludarabin and Cyclophosphamide (FC); 3 (8.5\%) chlorambucil; 5 (14.2\%) RituximabChlorambucil; $2(5.7 \%)$ the combination of
Rituximab, Cyclophosphamide, Doxorubicin, Vincristine, and Prednisone (R-CHOP); 2 (5.7\%) Bendamustine; 1 (2.8\%) the combination of cyclophosphamide, vincristine, and prednisone (CVP); and 1 (2.8\%) Rituximab-CVP. An analysis of treatmentbased survival time showed significantly different survival times $\left[\chi^{2}=3,887 ; p=0,049\right.$, Log Rank (Mantel-Cox)] test). The median overall survival of the untreated patients and treated patients were 99.4 months and 89.7 months, respectively (Graphics 1). The median survival time of the whole study group was 99.4 months(81.1-117.8) (Graphics 2). Thirty-eight $(22.5 \%)$ patients died.
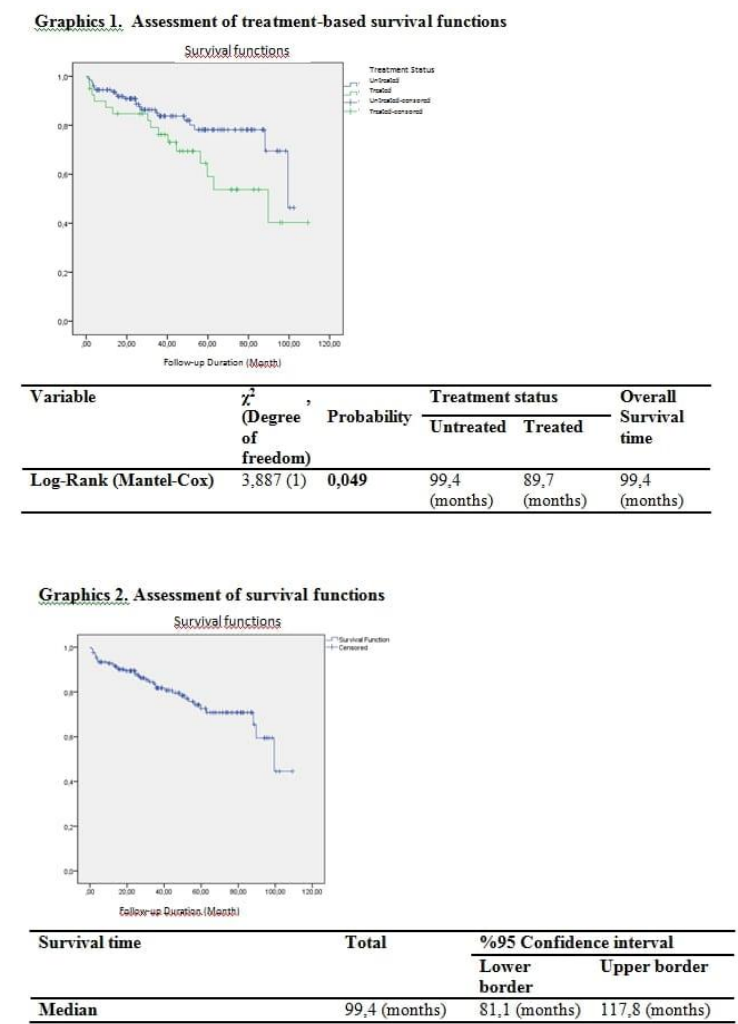

A Rai staging-based survival analysis showed significant differences between the survival times $\left(\chi^{2}=25,4 ; p<0,001\right.$, Log Rank (MantelCox) test). Patients with a Rai stage "0-1-2" had a mean survival time of 93.6 ay; those with a Rai stage of "3-4" had a mean survival time of 13.1 months. Patients with a Rai stage " $0-1$ 2 " had a significantly longer mean survival time than those with a Rai stage of " $3-4$ " (Graphics 3).

An age-based survival analysis showed significant differences between the age groups $\left[\chi^{2}=4,956 ; p=0,03\right.$ Log Rank (Mantel-Cox) 
test]. Patients aged $\leq 60$ years had a mean survival time of 89.7 months; those with a mean age of $>60$ years had a mean survival time of 99.4 months (Graphics 4).
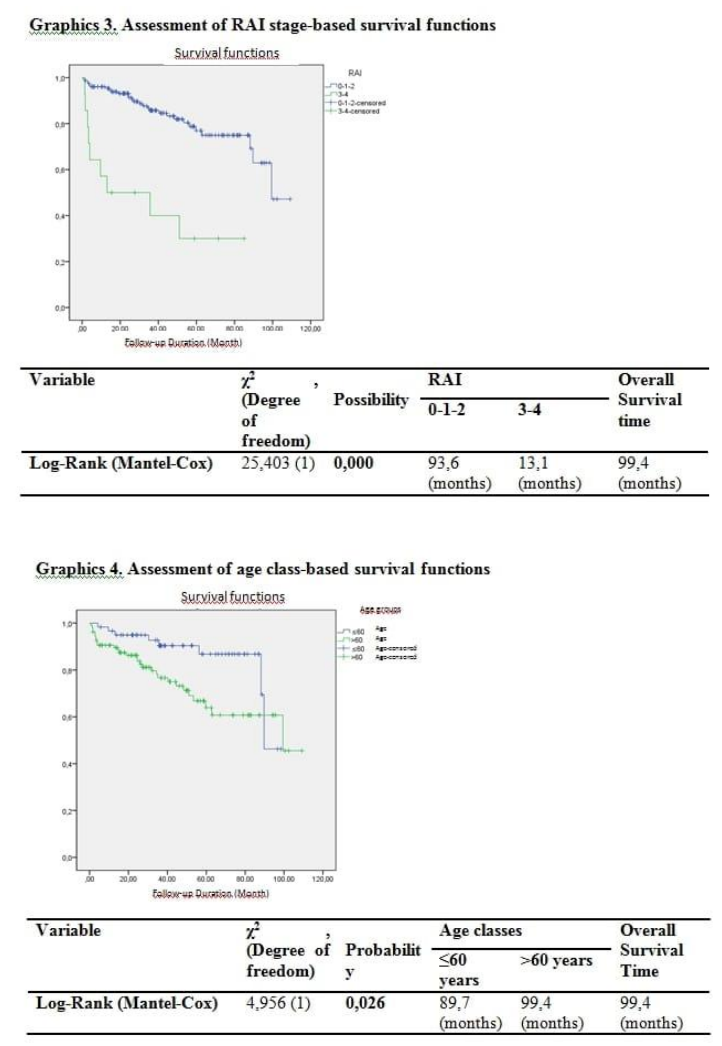

\section{DISCUSSION}

CLL is the most common leukemia type and usually affects elderly. The median age at onset was reported 63 years by a study and 64 years by another $(7,8)$. The median age of patients was 64 years in our study, which was consistent with the previous studies (9). CLL has a variable course, and survival time after diagnosis may vary greatly. The prognosis of CLL is assessed by clinical staging systems, albeit with some limitations. Today, although $80 \%$ of patients are diagnosed early, it cannot be predicted if the disease will have an aggressive or benign course, or at which stage treatment will be necessary (10). Our study demonstrated that patients $\leq 60$ years of age had a mean survival time of 89.7 years and those > 60 years of age had a mean survival time of 99.4 years. The number of patients with stage 3 and stage 4 at the time of initial diagnosis was 15 , but the number of patients who had no treatment indication at the time of diagnosis but required treatment at any time of the follow-up period was 42 patients.

It is well known that as the disease stage is increased, survival time is shortened and prognosis becomes worse. Our study demonstrated that the patients with an early Rai stage had a mean survival of 93.6 months while those with a later stage that required treatment had a mean survival time of 13.1 months. It was found that patients with early Rai stage had a longer mean survival time than those with later Rai stages, and this finding was in agreement with the literature data. The median lymphocyte count at the time of diagnosis was $16,6 \times 10^{4} / \mu \mathrm{L}$. In a study reported from England the lymphocyte count of CLL patients at the time of diagnosis was $<20 \times 10^{4} / \mu \mathrm{L}(11)$, which was in agreement with our findings. In two studies reported from Turkey the mean lymphocyte counts were $75,57 \times 10^{4} / \mu \mathrm{L}(12)$ and $34 \times 10^{4} / \mu \mathrm{L}(8)$. Close correlation of our patients mean lymphocyte count with those reported by former foreign studies may have stemmed from an early referral of patients presenting with lymphocytosis to our center. An increase in the incidence of secondary malignancies have been reported in CLL patients (13). Our study revealed that $15(8.9 \%)$ patients developed secondary malignancies during their follow-up. 10 of them were in the untreatment group, 5 were in the treatment group.

\section{CONCLUSION}

There is a limited number of studies about CLL patients in Turkey. Our findings are almost similar wit those reported by previous studies. In CLL patients diagnosis should be made at the right time; prognostic indexes should be determined; and the patient's risk group should be clearly ascertained. In case of treatment requirement, treatment plan should be made under the guidance of available guidelines. We aimed to review the clinical information about our CLL patients to contribute our country's overall CLL data.

\section{REFERENCES}

1. Hallek M, Cheson BD, Catovsky D, et al. Guidelines for the diagnosis and treatment of chronic lymphocytic leukemia: a report from the International Workshop on Chronic Lymphocytic Leukemia updating the National 
Cancer Institute-Working Group 1996 guidelines. Blood 2008;111:5446-56.

2. Montserrat E. New prognostic markers in CLL. Hematology Am Soc Hematol Educ Program 2006; 279284.

3. Thomas R, Ribeiro I, Shepherd P, et al. Spontaneous clinical regression in chronic lymphocytic leukaemia. $\mathrm{Br}$ J Haematol 2002; 116: 341-345.

4. Orchard JA, Ibbotson RE, Davis $\mathrm{Z}$, et al. ZAP-70 expression and prognosis in chronic lymphocytic leukaemia. Lancet. 2004;363(9403):105-11.

5. Crespo $\mathrm{M}$, Bosch $\mathrm{F}$, Villamor $\mathrm{N}$, et al. ZAP-70 expression as a surrogate for immunoglobulin-variableregion mutations in chronic lymphocytic leukemia. N Engl J Med. 2003; 348(18): 1764-75

6. Rosenquist R, Cortese D, Bhoi S, Mansouri L, Gunnarsson R. Prognostic markers and their clinical applicability in chronic lymphocytic leukemia: where do we stand? Leuk Lymphoma. 2013 Nov;54(11):2351-64.

7. Pamuk ON, Pamuk GE, Soysal T, Ongören S, Başlar Z, Ferhanoğlu B, Aydin Y, Ulkü B, Aktuğlu G, Akman N. Chronic lymphocytic leukemia in Turkey: experience of a single center in Istanbul. South Med J. 2004 Mar;97(3):240-5.

8. Demir V, Kahraman S, Katg1 A, Pişkin Ö, Özsan GH, Demirkan F, et al. Kronik Lenfositik Lösemi hastalarının genel klinik değerlendirilmesi. Dokuz Eylül Üniversitesi Tıp Fakültesi Dergisi 2012;26(1):9-19.
9. Redaelli A, Laskin BL, Stephens JM,et al. The clinical and epidemiological burden of chronic lymphocytic leukamia. Eur J Cancer Care 2004;13:279-87.

10. Hamblin TJ. Prognostic markers in chronic lympocytic leukaemia. Best Practice and Research Clinical Haematology 2007; 3:455-68.

11. Oscier DG, Gardiner AC, Kalıp SJ, et al. Multivariate analysis of prognostic factors in CLL: clinical stage, IGVH gene mutational status, and loss or mutation of the p53 gene are independent prognostic factors. Blood 2002;100: 1177-1184.

12. Medeni ŞS, Çetintepe $T$, Namdaroğlu S, Sarı R, Koçar M, Özden E, Bilgir O. Kronik Lenfositik Lösemi/Lenfoma Tanılı Hastalarımızın Retrospektif Değerlendirilmesi. İzmir Eğitim Ve Araştırma Hastanesi T1p Dergisi 2016; 20(3):87-94.

13. Kyasa MJ, Hazlet L, Rudolph SP, et al. Veterans with chronic lymphocytic leukemia/small lymphocytic lymphoma (CLL/SLL) have a markedly increased rate of second malignancy, which is the most common cause of death. Leuk Lymphoma 2004; 45: 507-513.

14. Moreno $\mathrm{C}$, Hodgson $\mathrm{K}$, Ferrer $\mathrm{G}$, et al. Autoimmune cytopenia in chronic lymphocytic leukemia: prevalence, clinical associations, and prognostic significance. Blood 116: $4771-4776$ 